\title{
HUBUNGAN KUALITAS TAMAN TERHADAP KETERIKATAN MASYARAKAT PADA TAMAN SIRING PIERRE TENDEAN KOTA BANJARMASIN
}

\author{
Rizky Ika Ramadhan, Wulan Dwi Purnamasari, Wisnu Sasongko \\ Jurusan Perencanaan Wilayah dan Kota Fakultas Teknik Universitas Brawijaya \\ Jalan Mayjen Haryono 167 Malang 65145 - Telp (0341)567886 \\ e-mail: rizky.ika14@student.ub.ac.id
}

\begin{abstract}
ABSTRAK
Taman Siring Pierre Tendean merupakan salah satu ruang publik yang terdapat di Kota Banjarmasin yang berbentuk ruang terbuka hijau dan memiliki berbagai macam fasilitas untuk mendukung aktivitas masyarakat. Ruang publik yang dapat mengakomodasi kebutuhan masyarakat untuk beraktivitas akan menciptakan keterikatan antara masyarakat dengan suatu ruang publik. Tujuan dari penelitian ini adalah untuk mengetahui kualitas Taman Siring Pierre Tendean berdasarkan indikator PPS (Project for Public Space), keterikatan masyarakat (place attachment), dan hubungan antara kualitas taman dengan keterikatan masyarakat. Metode yang digunakan dalam penelitian ini adalah dengan menggunakan IPA (Important Performance Analysis) untuk mengetahui kualitas Taman Siring Pierre Tendean, analisis tingkat place attachment untuk mengetahui keterikatan masyarakat pada Taman Siring Pierre Tendean, dan korelasi Pearson Product Moment untuk mengetahui kuat hubungan kualitas taman terhadap keterikatan masyarakat pada Taman Siring Pierre Tendean. Berdasarkan hasil analisis, dapat diketahui bahwa kualitas Taman Siring Pierre Tendean cukup baik, karena mayoritas atribut telah berada pada kuadran B dan D pada diagram kartesius. Keterikatan masyarakat pada Taman Siring Pierre Tendean dinilai tinggi $(3,25)$ dan termasuk dalam keterikatan level 3 "extention attachment". Berdasarkan hasil analisis korelasi, terdapat hubungan antara kualitas taman dengan keterikatan masyarakat pada Taman Siring Pierre Tendean dengan arah hubungan yang berbanding lurus dan kuat hubungan yang lemah. Adanya hubungan menunjukkan adanya perubahan pada kualitas taman akan menyebabkan terjadinya perubahan pada keterikatan masyarakat pada Taman Siring Pierre Tendean.
\end{abstract}

Kata Kunci : ruang-publik, kualitas-taman, keterikatan-masyarakat

\begin{abstract}
Siring Pierre Tendean Park is one of the public spaces in the city of Banjarmasin in the form of green open spaces and has a variety of facilities to support community activities. Public space that can accommodate the needs of the community for activities will create an attachment between the community and a public space. The purpose of this study was to determine the quality of the Siring Pierre Tendean Park based on PPS (Project for Public Space) indicators, place attachment, and the correlation between quality of park and place attachment. The methods used in this research are IPA (Important Performance Analysis) to determine the quality of Siring Pierre Tendean Park, place attachment level analysis to determine place attachment at Siring Pierre Tendean Park, and Pearson Product Moment correlation to determine the strength of correlation between park's quality and place attachment at Siring Pierre Tendean Park. Based on the results of the analysis, it can be seen that the quality of the Siring Pierre Tendean Park is pretty good, because the majority of attributes are in quadrants $B$ and $D$ in the Cartesian diagram. Place attachment at Siring Pierre Tendean Park was rated highly (3.25) and belong to level 3 attachment called "extention attachment". Based on the results of the correlation analysis, there is a relationship between the quality of the park and place attachment at the Siring Pierre Tendean Park. The direction of the correlation is directly proportional and the strength of the correlation is weak. The results of correlation indicate changes in park's quality will cause changes in place attachment to the Siring Pierre Tendean Park.
\end{abstract}

Keywords: public-space, quality-of-park, place-attachment

\section{PENDAHULUAN}

Ruang publik merupakan lingkungan alami maupun terbangun yang dikelola oleh umum maupun privat dimana masyarakat memiliki akses bebas terhadapnya (Carmona, 2008). Ruang publik dapat berupa jalan, lapangan terbuka, dan taman kota. Ruang publik menjadi pilihan masyarakat untuk melakukan interaksi karena menawarkan berbagai macam aktivitas di dalamnya yang dapat dinikmati bersama-sama. Sasongko, et al (2017), menyatakan bahwa suksesnya ruang publik tidak dapat dilihat hanya dari bentuk fisik ruang publik, tetapi juga perilaku penggunanya. Suatu ruang publik memiliki kualitas yang baik apabila sukses untuk memenuhi kualifikasi tertentu dan memuaskan penggunanya. Aktivitas yang dilakukan secara bersama-sama 
dalam suatu ruang publik akan membentuk ikatan antara masyarakat dengan suatu tempat. Ikatan dengan suatu tempat terbentuk karena banyaknya intensitas kontak yang terjadi antara masyarakat dengan suatu ruang publik yang menimbulkan rasa keakraban dan hubungan emosional antara masyarakat dengan suatu ruang publik. Keterikatan masyarakat terhadap suatu ruang dapat disebut dengan place attachment. Keterikatan seseorang pada suatu ruang akan membentuk ikatan yang positif yang disebabkan oleh adanya kepuasan terhadap ruang tersebut (Bonnes dan Secchiaroli, 1995, dalam Najafi dan Kamal, 2012). Keterikatan seseorang pada suatu ruang publik akan memberikan hubungan timbal balik terhadap kualitas taman, yang dapat dilihat dari perilaku pengunjung dalam menggunakan taman dan fasilitas di dalamnya.

Ruang terbuka yang terdapat di Kota Banjarmasin masih minim dan terbatas, yaitu kurang lebih 6\% dari total wilayah, dimana jumlah tersebut kurang dari yang dipersyaratkan oleh UU No. 26 Tahun 2007 yaitu seluas $30 \%$ dari total wilayah.. Taman Siring Pierre Tendean sebagai ruang publik yang mengakomodisir berbagai aktivitas masyarakat Kota Banjarmasin tentunya memiliki berbagai macam fasilitas untuk mendukung aktivitas masyarakat. Mayoritas masyarakat berkunjung ke Taman Siring Pierre Tendean pada saat weekend. Pada kondisi eksisting tidak jarang masih banyak fasilitas yang digunakan tidak sesuai dengan fungsi. Salah satu contohnya adalah masih banyak PKL yang berjuakan diluar lokasi yang telah ditentukan, yaitu sebanyak 400 PKL liar (Duta TV, 2019). Selain itu, PKL juga merusak dan menutupi fungsi fasilitas olahraga dan budaya (Purnamasari, 2019). Hal tersebut dikarenakan jalan yang seharusnya menjadi fasilitas untuk mobilisasi pengunjung dan fasilitas untuk pengunjung melakukan jogging terhalang oleh PKL yang berjualan. Banyaknya pengunjung dan PKL yang berjualan tentunya sangat berkaitan dengan sampah. Kesadaran pengunjung Taman Siring Pierre Tendean akan sampah masih kurang yang dilihat dari masih banyak terdapat sampah yang berserakan dan mengurangi kenyamanan pengunjung. Selain itu pengelolaan aktivitas wisata masih kurang baik, yang menyebabkan adanya beberapa aktivitas wisata yang ditutup sehingga mengecewakan pengunjung yang datang ke Taman Siring Pierre Tendean (Tribunnews, 2019).

Penurunan kualitas taman berhubungan dengan rasa keterikatan masyarakat pada Taman Siring Pierre Tendean. Kurangnya rasa keterikatan antara masyarakat dan Taman Siring Pierre
Tendean juga menjadi penyebab masyarakat kurang sadar akan perlunya menjaga kebersihan dan fasilitas yang disediakan, serta menggunakan fasilitas sesuai dengan fungsinya. Penelitian ini dilakukan untuk menilai kualitas Taman Siring Jalan Pierre Tendean sebagai ruang publik, menilai keterikatan masyarakat terhadap Taman Siring Pierre Tendean, dan hubungan kualitas Taman Siring Pierre Tendean terhadap keterikatan masyarakat pada Taman Siring Jalan Pierre Tendean.

\section{METODE PENELITIAN}

\section{Lokasi Penelitian}

Penelitian dilakukan pada Taman Siring Pierre Tendean yang terletak di sempadan Sungai Martapura, Jl. Pierre Tendean, Kota Banjarmasin. Taman Siring Pierre Tendean memiliki panjang $1,675 \mathrm{~km}$.

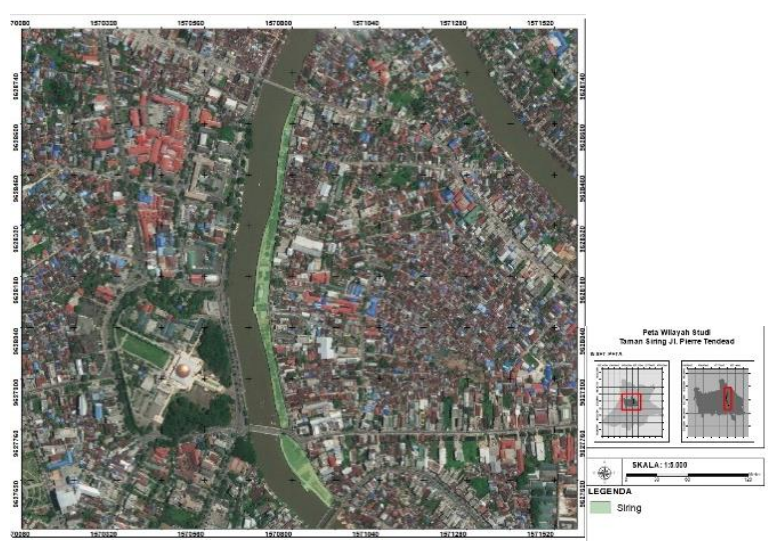

Gambar 1. Taman Siring Pierre Tendean

\section{Variabel Penelitian}

Variabel yang digunakan dalam penelitian ini ada 2 (dua), yaitu kualitas ruang publik dan place attachment. Sub variabel dari kualitas ruang publik berdasarkan dari place diagram PPS (Project for Pblic Space) ada 4 (empat), yaitu comfort \& image, access \& linkage, uses \& activity, dan sociability. Sedangkan sub variabel dari place attachment berdasarkan William \& Vaske (2003) ada 2 (dua), yaitu place identity dan place dependance. Indikator yang digunakan dalam penelitian dapat dilihat pada Tabel 1 .

\section{Tabel 1. Variabel Penelitian}

\begin{tabular}{ccll}
\hline Variabel & Sub Variabel & & \multicolumn{1}{c}{ Indikator } \\
\hline \multirow{2}{*}{$\begin{array}{c}\text { Kualitas } \\
\text { Ruang }\end{array}$} & Comfort \& & $\bullet$ & Keamanan (safety) \\
\cline { 3 - 3 } Publik & Image & $\bullet$ & Sejarah (history) \\
\cline { 3 - 3 } & & & $\begin{array}{l}\text { Menarik } \\
\text { (attractiveness) }\end{array}$ \\
\hline
\end{tabular}




\begin{tabular}{|c|c|c|}
\hline Variabel & Sub Variabel & Indikator \\
\hline & & $\begin{array}{ll}\text { - } & \text { Kerohanian } \\
& (\text { spirituality }) \\
\end{array}$ \\
\hline & & $\begin{array}{ll}- & \begin{array}{l}\text { Kemudahan untuk } \\
\text { duduk (sittability) }\end{array} \\
\end{array}$ \\
\hline & & 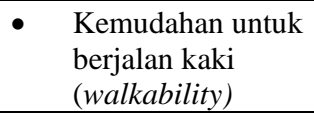 \\
\hline & & $\begin{array}{ll}\cdot & \begin{array}{l}\text { Kehijauan } \\
(\text { greeness })\end{array} \\
\end{array}$ \\
\hline & & $\begin{array}{ll} & \begin{array}{l}\text { Kebersihan } \\
(\text { cleanliness })\end{array} \\
\end{array}$ \\
\hline & \multirow{7}{*}{$\begin{array}{l}\text { Access \& } \\
\text { Linkage }\end{array}$} & $\begin{array}{ll} & \begin{array}{l}\text { Keterbacaan } \\
\text { (readability) }\end{array} \\
\end{array}$ \\
\hline & & $\begin{array}{ll}\text { - } & \begin{array}{l}\text { Kemudahan untuk } \\
\text { berjalan kaki } \\
\text { (walkablity) }\end{array} \\
\end{array}$ \\
\hline & & $\begin{array}{ll} & \begin{array}{l}\text { Keandalan } \\
\text { (realibility) }\end{array} \\
\end{array}$ \\
\hline & & $\begin{array}{ll} & \begin{array}{l}\text { Kontinuitas } \\
(\text { continuity })\end{array} \\
\end{array}$ \\
\hline & & $\begin{array}{ll}\text { - } & \text { Kedekatan } \\
(\text { proximity })\end{array}$ \\
\hline & & $\begin{array}{ll}- & \begin{array}{l}\text { Keterhubungan } \\
(\text { connectedness })\end{array} \\
\end{array}$ \\
\hline & & $\begin{array}{ll}- & \text { Kemudahan } \\
(\text { convenient })\end{array}$ \\
\hline & \multirow{8}{*}{$\begin{array}{l}\text { Uses \& } \\
\text { Activity }\end{array}$} & $\begin{array}{ll} & \begin{array}{l}\text { Keberlanjutan } \\
\text { (sustainability) }\end{array} \\
\end{array}$ \\
\hline & & $\begin{array}{ll} & \begin{array}{l}\text { Keunikan } \\
\text { (uniquences })\end{array} \\
\end{array}$ \\
\hline & & $\begin{array}{ll}\text { - } & \begin{array}{l}\text { Keterjangkauan } \\
\text { (affordability) }\end{array} \\
\end{array}$ \\
\hline & & $\begin{array}{l}\text { - } \begin{array}{l}\text { Menyenangkan } \\
\text { (fun) }\end{array} \\
\end{array}$ \\
\hline & & $\begin{array}{ll}- & \begin{array}{l}\text { Kegunaan } \\
\text { (usefullness) }\end{array} \\
\end{array}$ \\
\hline & & $\begin{array}{ll}- & \text { Perayaan } \\
& (\text { celebration }) \\
\end{array}$ \\
\hline & & $\begin{array}{ll}\text { - } & \begin{array}{l}\text { Daya Tahan } \\
\text { (vitality) }\end{array} \\
\end{array}$ \\
\hline & & $\begin{array}{ll} & \begin{array}{l}\text { Kearifan } \\
\text { (indigenous) }\end{array} \\
\end{array}$ \\
\hline & \multirow{8}{*}{ Sociability } & $\begin{array}{ll} & \begin{array}{l}\text { Kerja sama (co- } \\
\text { operation) }\end{array} \\
\end{array}$ \\
\hline & & $\begin{array}{ll}-\quad \begin{array}{l}\text { Keramahtamahan } \\
\text { (neighbourness) }\end{array} \\
\end{array}$ \\
\hline & & $\begin{array}{ll}- & \text { Pengelolaan } \\
& \text { (stewardship }) \\
\end{array}$ \\
\hline & & - $\quad$ Kebanggan (pride) \\
\hline & & $\begin{array}{ll}- & \begin{array}{l}\text { Keterbukaan } \\
(\text { welcoming })\end{array} \\
\end{array}$ \\
\hline & & $\begin{array}{ll}- & \begin{array}{l}\text { Keberagaman } \\
\text { (diversity) }\end{array} \\
\end{array}$ \\
\hline & & $\begin{array}{ll}- & \text { Keramahan } \\
& \text { (friendliness) }\end{array}$ \\
\hline & & $\begin{array}{ll} & \text { Interaktivitas } \\
\text { (interaktivity) }\end{array}$ \\
\hline \multirow{3}{*}{$\begin{array}{c}\text { Place } \\
\text { Attachment }\end{array}$} & \multirow{3}{*}{ Place Identity } & $\begin{array}{ll}- & \text { Ruang bagian dari } \\
& \text { seseorang }\end{array}$ \\
\hline & & $\begin{array}{ll}- & \text { Ruang spesial bagi } \\
& \text { seseorang } \\
\end{array}$ \\
\hline & & $\begin{array}{ll}- & \text { Seseorang } \\
& \text { teridentifikasi } \\
& \text { dengan suatu ruang } \\
\end{array}$ \\
\hline
\end{tabular}

\begin{tabular}{|c|c|c|}
\hline Variabel & Sub Variabel & Indikator \\
\hline & & $\begin{array}{ll}- & \text { Seseorang terikat } \\
\text { dengan suatu ruang }\end{array}$ \\
\hline & & $\begin{array}{ll} & \text { Suatu ruang } \\
\text { menggambarkan } \\
\text { diri seseorang }\end{array}$ \\
\hline & & $\begin{array}{ll}- & \text { Ruang memiliki } \\
\text { arti bagi seseorang }\end{array}$ \\
\hline & \multirow{6}{*}{$\begin{array}{c}\text { Place } \\
\text { Dependance }\end{array}$} & $\begin{array}{ll}- & \text { Ruang terbaik } \\
\text { untuk melakukan } \\
\text { aktivitas }\end{array}$ \\
\hline & & $\begin{array}{l}\text { Tidak terdapat } \\
\text { ruang lain yang } \\
\text { dapat } \\
\text { dibandingkan }\end{array}$ \\
\hline & & $\begin{array}{ll}\text { - } & \text { Kepuasan lebih } \\
\text { saat mengunjungi } \\
\text { suatu ruang }\end{array}$ \\
\hline & & $\begin{array}{l}\text { - Melakukan } \\
\text { aktivitas di suatu } \\
\text { ruang lebih penting } \\
\text { daripada ruang } \\
\text { lainnya } \\
\end{array}$ \\
\hline & & $\begin{array}{l}\text { Ruang yang tidak } \\
\text { dapat tergantikan }\end{array}$ \\
\hline & & $\begin{array}{l}\text { - Menyenangkan } \\
\text { untuk melakukan } \\
\text { aktivitas pada } \\
\text { ruang lain yang } \\
\text { mirip }\end{array}$ \\
\hline
\end{tabular}

\section{Metode Pengumpulan Data}

Metode pengumpulan data yang digunakan, yaitu menggunakan survei primer dan survei sekunder. Survei primer digunakan untuk memperoleh data secara langsung di lapangan, yang dilakukan dengan cara obesrvasi dan kuisioner. Pengambilan data dilakukan dengan mengambil data dari sebagian populasi. Populasi Taman Siring Pierre Tendean adalah seluruh pengunjung yang berkunjung ke taman. Survei sekunder dilakukan dengan memperoleh data yang diperlukan ke instansi yang berkaitan dengan penelitian.

\section{Pemilihan sampel}

Metode pengambilan sampel yang digunakna yaitu metode simple random sampling dengan teknik sampling yang digunakan dalam penentuan sampel responden penelitian, yaitu menggunakan Linier Time Function Sample. Linier Time Function Sample digunakan untuk menentukan jumlah sampel yang akan diambil karena jumlah populasi pengunjung yang mengunjungi taman tidak diketahui secara pasti. Perhitungan jumlah sampel dengan menggunakan teknik Linier Time Function Sample menggunakan rumus berikut (Sari, 1993 dalam Pattisinai, 2016): 


$$
\begin{aligned}
& \mathrm{n}=\frac{(t-t 0)}{t i} \\
& \mathrm{n}=\frac{((8 \times 14)-(4,5 \times 14))}{0,41} \\
& \mathrm{n}=119,51 \text { responden } \approx 120 \text { responden }
\end{aligned}
$$

$$
\begin{aligned}
& \text { Keterangan : } \\
& \text { n : jumlah sampel yang digunakan } \\
& \mathrm{t} \text { :waktu yang tersedia untuk melakukan } \\
& \text { penelitian } \\
& \text { t0 : waktu pengambilan sampel } \\
& \text { t1 : waktu yang dibutuhkan oleh seseorang } \\
& \text { untuk mengisi kuisioner }
\end{aligned}
$$

\section{Metode Analisis}

\section{Analisis IPA}

Kualitas adalah derajat keunggulan yang dinyatakan dengan terpenuhinya kebutuhan pengunjung (satisfy the needs of costumer) (Neil Johnson dalam Willie, 1992 dalam Malek, dkk, 2009). Berdasarkan definisi tersebut, kualitas taman dapat diketahui dengan menilai kepuasan masyarakat terhadap Taman Siring Pierre Tendean dengan menggunakan IPA. Importance Performance Analysis (IPA) digunakan untuk menilai tingkat kepentingan dan tingkat kinerja dari Taman Siring Pierre Tendean. Kepuasan pengguna Taman Siring Pierre Tendean dilihat dari perbedaan nilai kinerja dan kepentingan. Perbedaan yang bernilai negatif menggambarkan ketidakpuasan pengguna taman dan apabila bernilai positif menggambarkan kepuasan pengguna taman. Komponen kualitas ruang publik yang dinilai menggunakan IPA adalah comfort \& image, access \& linkage, uses \& activity, dan sociability. Hasil dari Importance Performance Analysis (IPA) berupa kepuasan pengguna taman berdasarkan nilai kinerja dan nilai kepentingan masing-masing atribut. Rata-rata nilai kinerja dan nilai kepentingan masing-masing atribut digambarkan dalam grafik 2-dimensi yang disebut diagram kartesius untuk melihat pelayanan atribut secara mudah dan menentukan langkah yang akan diambil selanjutnya

\section{Analisis tingkat place attachment}

Analisis tingkat place attachment digunakan untuk mengidentifikasi keterikatan masyarakat pada Taman Siring Pierre Tendean. Place attachment diukur dengan menghitung jumlah nilai masing-masing responden dari masing-masing variabel place attachment, yaitu place identity dan place dependance. Place identity merupakan emosional attachment yang mengacu pada arti penting simbolis dari suatu tempat sebagai tempat yang menyimpan berbagai emosi dan hubungan yang memberikan makna dan tujuan kepada hidup seseorang (Williams dan Roggenbuck 1989, Shamai 1991, Giuliani dan Feldman 1993, dalam William dan Vaske, 2003). Vaske dan Kobrin (2001, dalam William dan Vaske, 2003) menyatakan bahwa place identity sangat kuat berkaitan dengan ukuran perilaku yang bertanggung jawab terhadap lingkungan. Sedangkan place dependence merupakan fungsional attachment yang merefleksikan pentingnya sebuah tempat dalam menyediakan fasilitas dan kondisi yang mendukung tujuan tertentu atau aktivitas yang diinginkan seseorang (Schreyer et al. 1981, Stokols dan Shumaker 1981, Williams dan Roggenbuck 1989, dalam William dan Vaske, 2003). Place dependance akan meningkat apabila tempat tersebut memiliki jarak cukup dekat sehingga seseorang akan sering mengunjungi tempat tersebut.

Place attachment dihitung dengan menggunakan data berdasarkan hasil kuisioner yang dilakukan. Kuisioner place attachment terdiri dari 12 (dua belas) pertanyaan berdasarkan indikator place identity dan place dependance. Penilaian dilakukan mengunakan skala likert 1-5 dari sangat tidak setuju hingga sangat setuju. Hasil kuisioner akan dikelompokkan menjadi 4 (empat) kategori untuk setiap atribut dan variabel place attachment. Kategori keterikatan masyarakat, yaitu sangat tinggi, tinggi, rendah, dan sangat rendah. Selanjutnya hasil kuisioner masingmasing responden dinilai dan diklasifikasikan untuk mengetahui keterikatan masing-masing responden pada Taman Siring Pierre Tendean. Place attachment dinilai untuk masing-masing responden, karena setiap orang akan memiliki place attachment yang berbeda antara satu dengan yang lainnya. Hasil kuisioner akan dikelompokkan menjadi 4 (empat) kategori sehingga didapat tingkat keterikatan masyarakat pada Taman Siring Pierre Tendean. Kategori place attachment, yaitu tidak terikat sama sekali, cenderung tidak terikat, cenderung terikat, dan sangat terikat.

\section{Analisis korelasi}

Korelasi merupakan analisis hubungan yang bertujuan untuk mengetahui kekuatan hubungan antara 2 (dua) variabel, yaitu variabel kualitas taman (X) dengan variabel place attachment (Y). Nilai koefisien korelasi (r) menggambarkan kekuatan hubungan antara kualitas taman dengan place attachment, yaitu berada diantara -1 dan $1(\mathrm{r}=-1 \leq 0 \leq 1)$. Apabila hasil nilai signifikansi $<0,05$ maka terdapat 
hubungan antara kualitas Siring Jalan Pierre Tendean dengan place attachment. Hipotesis yang digunakan dalam analisis korelasi adalah sebagai berikut:

$\mathrm{HO}=$ Tidak terdapat pengaruh antara kualitas Siring Jalan Pierre Tendean terhadap keterikatan masyarakat pada Siring Jalan Pierre Tendean.

H1 = Terdapat pengaruh antara kualitas Siring Jalan Pierre Tendean terhadap keterikatan masyarakat pada Siring Jalan Pierre Tendean

Tabel 2. Nilai korelasi dan tingkat kekuatan hubungan

\begin{tabular}{cll}
\hline No & \multicolumn{1}{c}{ Nilai Korelasi (r) } & Tingkat Hubungan \\
\hline 1 & $0,00-0,199$ & Sangat Lemah \\
\hline 2 & $0,20-0,399$ & Lemah \\
\hline 3 & $0,40-0,599$ & Cukup \\
\hline 4 & $0,60-0,799$ & Kuat \\
\hline 5 & $0,80-0,100$ & Sangat Kuat \\
Sumber : Siregar, Syofian, 2017 &
\end{tabular}

\section{HASIL DAN PEMBAHASAN}

Taman Siring Pierre Tendean terbagi menjadi 2 (dua) bagian, yaitu pada bagian utara yang dalam perencanaannya termasuk dalam kawasan 1 memiliki panjang $1.300 \mathrm{~m}$ dan pada bagian selatan yang dalam perencanaannya termasuk dalam kawasan 2 memiliki panjang 375 m. Taman Siring Pierre Tendean sebagai suatu ruang publik digunakan masyarakat untuk melakukan berbagai macam aktivitas. Terdapat berbagai macam fasilitas yang terdapat di Taman Siring Pierre Tendean dalam rangka menunjang aktivitas yang dilakukan masyarakat selama mengunjungi di siring.

\section{Tabel 3. Fasitas Taman Siring Pierre Tendean}

\begin{tabular}{|c|c|c|c|}
\hline No & Fasilitas & Jenis Fasilitas & $\begin{array}{c}\text { Jumlah } \\
\text { (unit) }\end{array}$ \\
\hline \multirow{3}{*}{1} & \multirow{3}{*}{ Lampu Siring } & Lampu Siring & 66 \\
\hline & & $\begin{array}{l}\text { Lampu Siring } \\
\text { Tenaga Surya }\end{array}$ & 42 \\
\hline & & Lampu Besar & 5 \\
\hline \multirow{3}{*}{2} & \multirow{3}{*}{$\begin{array}{l}\text { Tempat } \\
\text { Sampah }\end{array}$} & $\begin{array}{l}3 \text { Warna (50 } \\
\text { liter) }\end{array}$ & 6 \\
\hline & & Besar (50 liter) & 10 \\
\hline & & Kecil & 82 \\
\hline \multirow{3}{*}{3} & \multirow{3}{*}{$\begin{array}{l}\text { Tempat } \\
\text { Duduk }\end{array}$} & Persegi Panjang & 35 \\
\hline & & Balok & 12 \\
\hline & & Silinder & 36 \\
\hline 4 & $\begin{array}{l}\text { Papan } \\
\text { Penanda } \\
\text { (Signage) }\end{array}$ & - & 33 \\
\hline 5 & $\begin{array}{l}\text { Lapangan } \\
\text { Basket }\end{array}$ & - & 2 \\
\hline
\end{tabular}

\begin{tabular}{|c|c|c|c|}
\hline No & Fasilitas & Jenis Fasilitas & $\begin{array}{c}\text { Jumlah } \\
\text { (unit) }\end{array}$ \\
\hline 6 & $\begin{array}{l}\text { Playground } \\
\text { Anak-Anak }\end{array}$ & - & 1 \\
\hline 7 & Toilet & - & 3 \\
\hline 8 & $\begin{array}{l}\text { Fasilitas untuk } \\
\text { Difabel }\end{array}$ & - & 2 \\
\hline 9 & CCTV & - & 2 \\
\hline \multirow{5}{*}{10} & \multirow{5}{*}{$\begin{array}{l}\text { Daya Tarik } \\
\text { Fisik }\end{array}$} & $\begin{array}{l}\text { Menara } \\
\text { Pandang }\end{array}$ & 1 \\
\hline & & $\begin{array}{l}\text { Rumah Anno } \\
1925\end{array}$ & 1 \\
\hline & & $\begin{array}{l}\text { Patung } \\
\text { Bekantan }\end{array}$ & 1 \\
\hline & & Pasar Terapung & 1 \\
\hline & & $\begin{array}{l}\text { Wisata Susur } \\
\text { Sungai }\end{array}$ & 1 \\
\hline
\end{tabular}

\section{Karakteristik Pengunjung}

Taman Siring Pierre Tendean merupakan salah satu ruang publik yang dapat dikunjungi secara bebas oleh siapa saja tanpa adanya larangan bagi kelompok tertentu. Purnamasari, dkk (2017) dalam penelitiannya mengemukakan bahwa penggunaan ruang publik paling tinggi pada saat weekend dibandingkan dengan weekday. Hal tersebut dikarenakan keberagaman pengunjung, dimana mayoritas pengunjung merupakan masyarakat yang termasuk dalam golongan usia bekerja. Mayoritas pengunjung mengunjungi Taman Siring Pierre Tendean 1x dalam seminggu (47\%). Hal tersebut dikarenakan pada saat weekend terdapat Pasar Terapung dan kuliner yang menarik masyarakat untuk datang berkunjung setiap minggu. Selain itu, Taman Siring Pierre Tendean terletak dekat dengan kawasan CFD (Car Free Day), sehingga pada saat weekend banyak pengunjung yang menuju ke Taman Siring Pierre Tendean seletah berolahraga. Masyarakat berkunjung ke Taman Siring Pierre Tendean ada yang bersama keluarga, teman, keluarga dan teman, dan sendirian. Pengunjung Taman Siring Pierre Tendean beraneka ragam mulai dari bayi hingga orang dewasa.

Tabel 4. Karakteristik pengunjung berdasarkan jenis kelamin dan kelompok usia

\begin{tabular}{cccc}
\hline \multirow{2}{*}{$\begin{array}{c}\text { Kelompok } \\
\text { Umur }\end{array}$} & $\begin{array}{c}\text { Perempuan } \\
\text { (orang) }\end{array}$ & $\begin{array}{c}\text { Laki- } \\
\text { Laki } \\
\text { (orang) }\end{array}$ & $\begin{array}{c}\text { Jumlah } \\
\text { (orang) }\end{array}$ \\
\cline { 2 - 4 } $12-25$ tahun & 54 & 32 & 86 \\
\hline $26-45$ tahun & 18 & 3 & 21 \\
\hline $46-65$ tahun & 11 & 2 & 13 \\
\hline Jumlah & $\mathbf{8 6}$ & $\mathbf{3 4}$ & $\mathbf{1 2 0}$ \\
\hline
\end{tabular}

Berdasarkan Tabel 3 dapat diketahui bahwa mayoritas pengunjung adalah perempuan remaja (12-25 tahun) yang berjumlah 54 orang atau $45 \%$ 
dari total responden. Mayoritas pengunjung merupakan perempuan menunjukkan bahwa Taman Siring Pierre Tendean memberikan rasa aman untuk melakukan berbagai macam aktivitas. Keamanan suatu ruang publik dapat dilihat dari jumlah pengguna perempuan yang banyak melakukan aktivitas pada suatu ruang publik. Secara keseluruhan, pengunjung paling banyak merupakan pengunjung dalam kelompok usia remaja (12-25 tahun) yaitu sebanyak 86 orang atau $71,67 \%$ dari total responden. Pengunjung remaja yang datang berkunjung ke Taman Siring Pierre Tendean biasanya datang dengan teman dan melakukan aktivitas berkumpul dan mengobrol sambil duduk-duduk memandang sungai.

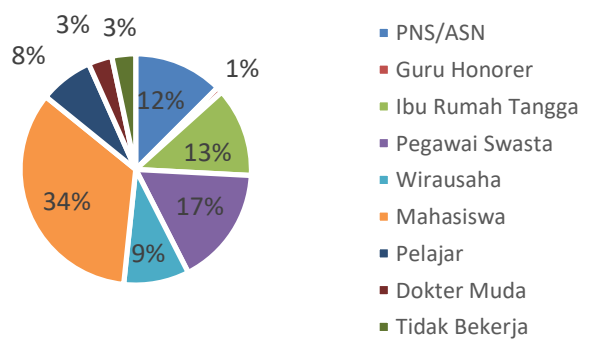

\section{Gambar 2. Karakteristik Pengunjung Berdasarkan Jenis Pekerjaan}

Berdasarkan jenis pekerjaan, mayoritas pengunjung merupakan mahasiswa yaitu berjumlah 41 orang dengan persentase $34 \%$. Pengunjung mahasiswa yang berkunjung ke Taman Siring Pierre Tendean biasanya datang bersama teman. Mahasiswa yang datang ke
Taman Siring Pierre Tendean biasanya melakukan aktivitas berkumpul atau melakukan acara yang diselenggarakan oleh mahasiswa, dan olahraga. Pengunjung yang cukup banyak mengunjungi Taman Siring Pierre Tendean terdapat pegawai swasta, ibu rumah tangga, PNS/ASN, wirausaha, pelajar, dokter muda, dan pengunjung yang tidak bekerja. Mayoritas pengunjung yang datang berkunjung ke Taman Siring Pierre Tendean banyak yang melakukan aktivitas berbelanja di Pasar Terapung, menikmati kuliner khas Banjar, dan wisata susur sungai.

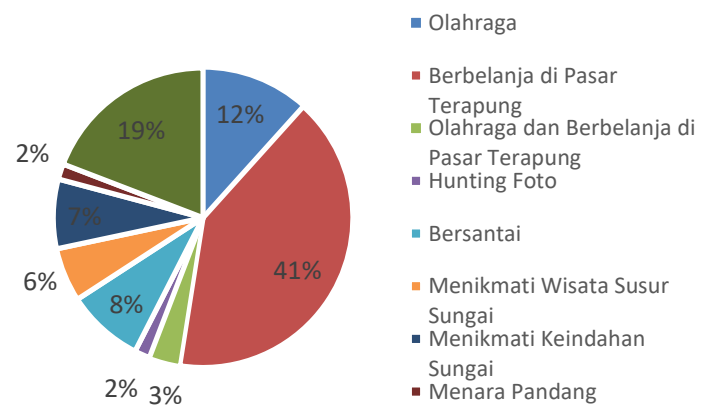

Gambar 3. Alasan Berkunjung

\section{Karakteristik Taman Siring Pierre Tendean Berdasarkan Indikator PPS (Project for Public Space)}

Project for Public Space (2000) dalam Carmona (2008) menyatakan bahwa ruang publik yang sukses memiliki 4 (empat) atribut, yaitu comfort \& image, access \& linkage, uses \& activity, dan sociability.

\section{Tabel 5. Karakteristik Taman Siring Pierre Tendean berdasarkan indikator PPS}

\begin{tabular}{|c|c|c|}
\hline Variabel & Atribut & $\begin{array}{l}\text { Karakteristik } \\
\end{array}$ \\
\hline \multirow{8}{*}{$\begin{array}{l}\text { Comfort } \\
\text { \& Image } \\
(X 1)\end{array}$} & Keamanan & $\begin{array}{l}\text { Taman Siring Pierre Tendean memiliki lampu taman, CCTV, dan mayoritas pengunjung } \\
\text { merupakan perempuan. }\end{array}$ \\
\hline & Sejarah & Terdapat bangunan Rumah Panggung khas Banjar yang berdiri dari Tahun 1925. \\
\hline & Menarik & $\begin{array}{l}\text { Taman Siring Pierre Tendean memiliki daya tarik yang menjadi ciri yang } \\
\text { menggambarkan kebudayaan dari Kota Banjarmasin, yaitu Menara Pandang, Rumah } \\
\text { Anno Tahun 1925, Patung Bekantan, Pasar Terapung, dan wisata susur sungai. }\end{array}$ \\
\hline & Kerohanian & $\begin{array}{l}\text { Taman Siring Pierre Tendean memiliki fasilitas mesjid hijau serta terletak dekat dengan } \\
\text { Mesjid Sabilal Muhtadin dan Klenteng Soetji Nurani. }\end{array}$ \\
\hline & $\begin{array}{l}\text { Kemudahan } \\
\text { untuk duduk }\end{array}$ & $\begin{array}{l}\text { Taman Siring Pierre Tendean memiliki } 83 \text { tempat duduk yang tersebar di sepanjang } \\
\text { Taman Siring Pierre Tendean dan semua tempat duduk dapat digunakan. }\end{array}$ \\
\hline & $\begin{array}{l}\text { Kemudahan } \\
\text { untuk berjalan } \\
\text { kaki }\end{array}$ & $\begin{array}{l}\text { Taman Siring Pierre Tendean memiliki desain yang menyediakan jalur untuk pejalan } \\
\text { kaki. }\end{array}$ \\
\hline & Kehijauan & Taman Siring Pierre Tendean memiliki pepohonan yang tersebar si sepanjang taman. \\
\hline & Kebersihan & $\begin{array}{l}\text { Terdapat petugas kebersihan dan bak sampah yang berjumlah } 98 \text { buah, tetapi terdapat } \\
\text { pengunjung yang membuang sampah sembarangan. }\end{array}$ \\
\hline \multirow{2}{*}{$\begin{array}{l}\text { Access \& } \\
\text { Linkage } \\
(X 2)\end{array}$} & Keterbacaan & $\begin{array}{l}\text { Secara visual, keterbacaan dapat dilihat dari kemudahan ruang publik dilihat dari } \\
\text { kejauhan. Taman Siring Pierre Tendean dapat dilihat dengan jelas dari Jl. Jenderal } \\
\text { Sudirman, Jembatan Merdeka, Jembatan Pasar Lama, dan Jembatan Dewi. }\end{array}$ \\
\hline & $\begin{array}{l}\text { Kemudahan } \\
\text { untuk berjalan } \\
\text { kaki }\end{array}$ & $\begin{array}{l}\text { Taman Siring Pierre Tendean telah memiliki fasilitas bagi pejalan kaki dan terhubung } \\
\text { dengan jalur pejalan kaki diluar siring. }\end{array}$ \\
\hline
\end{tabular}




\begin{tabular}{|c|c|c|}
\hline Variabel & Atribut & Karakteristik \\
\hline & Keandalan & $\begin{array}{l}\text { Pengunjung menilai keandalan Taman Siring Pierre Tendean baik yang dapat dilihat dar } \\
\text { pengunjung dapat dengan mudah mengunjungi taman berkali-kali dan melakukan } \\
\text { aktivitas secara bebas. }\end{array}$ \\
\hline & Kontinuitas & $\begin{array}{l}\text { Masyarakat dapat mengunjungi Taman Siring Pierre Tendean setiap saat dan tidak } \\
\text { terdapat batasan fisik, seperti pagar dalam memasui siring, tetapi terdapat perbadaan } \\
\text { ketinggian yang membedakan Taman Siring Pierre Tendean dengan jalan. }\end{array}$ \\
\hline & Kedekatan & $\begin{array}{l}\text { Taman Siring Pierre Tendean terletak di sepanjang Sungai Martapura dan berhadapan } \\
\text { dengan bangunan sekitar. }\end{array}$ \\
\hline & Keterhubungan & $\begin{array}{l}\text { Taman Siring Pierre Tendean terkoneksi dengan jalur pejalan kaki dan siring yang berada } \\
\text { di seberang Taman Siring Pierre Tendean. Taman Siring Pierre Tendean tidak terkoneks } \\
\text { dengan jalur angkutan umum. }\end{array}$ \\
\hline & Kemudahan & $\begin{array}{l}\text { Taman Siring Pierre Tendean memiliki fasilitas disabilitas, yaitu jalur untuk pengguna } \\
\text { kursi roda } 2 \text { (dua) buah dan jalur untuk tunanetra, tetapi fasilitas tersebut dalam kondis } \\
\text { tidak layak pakai/rusak. }\end{array}$ \\
\hline \multirow{8}{*}{$\begin{array}{l}\text { Uses \& } \\
\text { Activity } \\
(X 3)\end{array}$} & Keberlanjutan & $\begin{array}{l}\text { Pada Taman Siring Pierre Tendean selalu terdapat aktivitas pada saat pagi, sore, maupun } \\
\text { malam hari. Selain itu terdapat aktivitas rutin yang selalu ada seperti, wisata susur sungai } \\
\text { yang ada setiap hari, serta Pasar Terapung dan kuliner saat weekend. }\end{array}$ \\
\hline & Keunikan & $\begin{array}{l}\text { Keunikan yang dimiliki Taman Siring Pierre Tendean yang membedakan dengan ruang } \\
\text { publik lainnya yaitu adanya aktivitas wisata, seperti wisata susur sungai dan Pasar } \\
\text { Terapung. Selain itu terdapat ikon Kota Banjarmasin, seperti Patung Bekantan dan } \\
\text { Menara Pandang yang tidak terdapat pada ruang publik lain. }\end{array}$ \\
\hline & Keterjangkauan & $\begin{array}{l}\text { Taman Siring Pierre Tendean merupakan ruang publik yang tidak terdapat karcis masuk, } \\
\text { sehingga pengunjung dapat secara bebas melakukan berbagai aktivitas tanpa adanya } \\
\text { pungutan biaya. }\end{array}$ \\
\hline & Menyenangkan & $\begin{array}{l}\text { Taman Siring Pierre Tendean memiliki berbagai macam aktivitas yang dapat dinikmati } \\
\text { terutama pada saat weekend, dimana terdapat Pasar Terapung dan kuliner yang menjual } \\
\text { berbagai makanan khas Banjar yang menarik masyarakat untuk berkunjung. }\end{array}$ \\
\hline & Kegunaan & $\begin{array}{l}\text { Masyarakat yang datang berkunjung ke Taman Siring Pierre Tendean dapat melakukan } \\
\text { berbagai macam aktivitas, seperti berkumpul, berbelanja, olahraga, bersantai, dan banyak } \\
\text { kegiatan lainnya yang memberikan manfaat bagi pengunjung. }\end{array}$ \\
\hline & Perayaan & $\begin{array}{l}\text { Hampir setiap bulan terdapat berbagai macam festival yang dilaksanakan di Taman Siring } \\
\text { Pierre Tendean. Contoh perayaan yang terdapat di Taman Siring Pierre Tendean yaitu } \\
\text { Festival Sungai dan Festival Jukung Banjar. }\end{array}$ \\
\hline & Daya tahan & $\begin{array}{l}\text { Masyarakat dapat melakukan berbagai macam aktivitas sepanjang hari di Taman Siring } \\
\text { Pierre Tendean tanpa adanya batasan. Hal tersebut dapat dilihat dari adanya aktivitas di } \\
\text { Taman Siring Pierre Tendean pada saat pagi, sore, maupun malam saat weekday maupun } \\
\text { weekend. Pada saat weekend, terutama pada pagi hari, terdapat berbagai macam aktivitas } \\
\text { yang dilakukan pengunjung, yaitu terdapat } 25 \text { jenis aktivitas. }\end{array}$ \\
\hline & Kearifan & $\begin{array}{l}\text { Pada Taman Siring Pierre Tendean terdapat aktivitas yang memiliki nilai kebudayaan } \\
\text { suku Banjar, seperti adanya pertunjukan musik Banjar. Selain itu, terdapat juga aktivitas } \\
\text { dari suku Dayak, yaitu pertunjukan tarian Dayak. }\end{array}$ \\
\hline \multirow{8}{*}{$\begin{array}{l}\text { Sociability } \\
(X 4)\end{array}$} & Kerja sama & $\begin{array}{l}\text { Kerja sama dengan masyarakat yang terdapat di Taman Siring Pierre Tendean yaitu kerja } \\
\text { sama dalam mengelola aktivitas wisata susur sungai, kuliner, dan Pasar Terapung. }\end{array}$ \\
\hline & Keramahtamahan & $\begin{array}{l}\text { Salah satu aktivitas yang dilakukan anak-anak di sekitar Taman Siring Pierre Tendean } \\
\text { adalah berenang bersama-sama di sungai. }\end{array}$ \\
\hline & Pengelolaan & $\begin{array}{l}\text { Aktivitas seperti kuliner di Taman Siring Pierre Tendean dikelola oleh pemerintah yang } \\
\text { bekerja sama dengan masyarakat. Pengelolaan Pasar Terapung merupakan kerjasama } \\
\text { antara Pemerintah dengan penjual yang berjualan di atas klotok (acil-acil). }\end{array}$ \\
\hline & Kebanggaan & $\begin{array}{l}\text { Pengunjung Taman Siring Pierre Tendean merasa bangga terhadap Taman Siring Pierre } \\
\text { Tendean karena Taman Siring Pierre Tendean merupakan ruang dimana terdapat } \\
\text { kebudayaan Banjar dan merupakan salah satu lokasi wisata di Kota Banjarmasin. }\end{array}$ \\
\hline & Keterbukaan & $\begin{array}{l}\text { Taman Siring Pierre Tendean terletak tepat di tengah kota dan dapat dengan mudah } \\
\text { terlihat dari jalan. Taman Siring Pierre Tendean tidak memiliki pagar/pembatas pada } \\
\text { bagian yang berhadapan dengan jalan, sehingga masyarakat dapat dengan bebas } \\
\text { memasuki Taman Siring Pierre Tendean. }\end{array}$ \\
\hline & Keberagaman & $\begin{array}{l}\text { Pengunjung Taman Siring Pierre Tendean beraneka ragam dari berbagai macam keompok } \\
\text { usia dan pekerjaan. }\end{array}$ \\
\hline & Keramahan & $\begin{array}{l}\text { Taman Siring Pierre Tendean ramah terhadap anak-anak dan lansia, tetapi kurang ramah } \\
\text { terhadap pengguna disabilitas. }\end{array}$ \\
\hline & Interaktivitas & $\begin{array}{l}\text { Pengunjung Taman Siring Pierre Tendean mayoritas mengunjungi siring bersama teman } \\
\text { keluarga, maupun bersama teman dan keluarga. Pengunjung yang berkunjung bersama } \\
\text { teman dan keluarga menimbulkan adanya interaksi antar satu sama lain. }\end{array}$ \\
\hline
\end{tabular}




\section{Kualitas Taman Siring Pierre Tendean sebagai Ruang Publik}

Sasongko, et al (2017), menyatakan bahwa suksesnya ruang publik tidak dapat dilihat hanya dari bentuk fisik ruang publik, tetapi juga perilaku penggunanya. Taman Siring Pierre Tendean sebagai ruang publik dinilai berdasarkan persepsi pengunjung siring terhadap variabel ruang publik yang sukses. Kualitas adalah derajat keunggulan yang dinyatakan dengan terpenuhinya kebutuhan pengunjung (satisfy the needs of costumer) (Neil Johnson dalam Willie, 1992 dalam Malek, dkk, 2009). Kualitas suatu ruang publik dapat diukur dengan menggunakan 4 (empat) atribut ruang sebagai ruang publik yang baik berdasarkan Project for Public Space (PPS), yaitu comfort \& good image, access \& linkage, uses \& activity, dan sociability. Terdapat 31 atribut yang digunakan untuk menilai kualitas Taman Siring Pierre Tendean berdasarkan persepsi masyarakat.

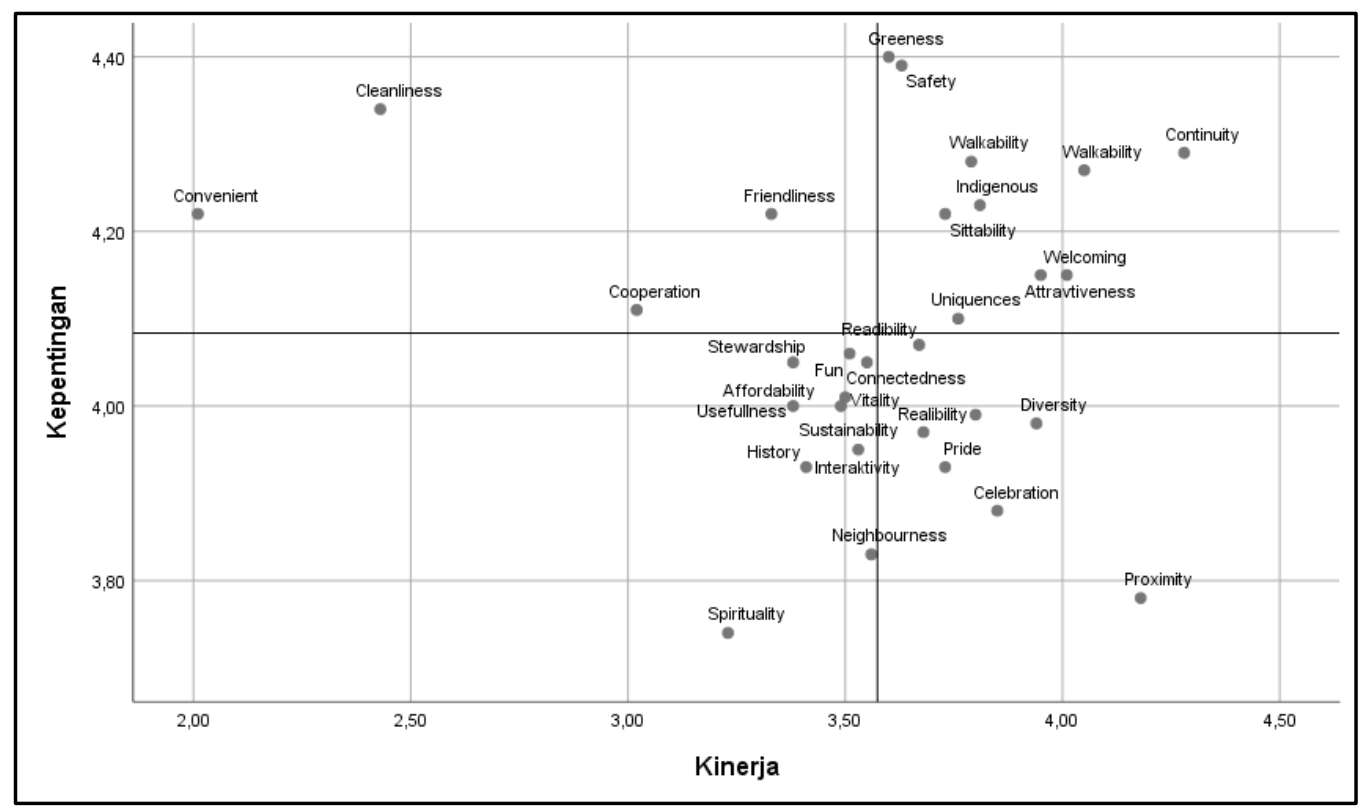

Gambar 4. Diagram Kartesius Atribut Kualitas Taman

Berdasarkan Gambar 4, masing-masing atribut dikelompokkan menjadi 4 (empat) kelompok, yaitu:

1. Kuadran A (Prioritas Utama)

Atribut-atribut yang termasuk dalam Kuadean A pada diagram kartesius adalah cleanliness yang termasuk dalam variabel comfort \& image, convenient yang termasuk dalam variabel access \& linkage, cooperation dan friendliness yang termasuk dalam variabel sociability. Atribut yang berada di kuadran A memiliki kepentingan yang tinggi, tetapi kinerja atribut rendah. Atribut-atribut tersebut perlu diprioritaskan penanganannya karena pengunjung merasa kinerja dari atribut-atribut tersebut masih kurang, namun kepentingan dianggap sangat penting bagi pengunjung.

2. Kuadran B (Pertahankan Prestasi)

Atribut-atribut yang termasuk dalam kuadran B pada diagram kartesius adalah safety, sittability, attractiveness, walkability dan greeness dalam variabel comfort \& image, walkability, continuity dalam variabel access \& linkage, uniqueness dan indigeneous dalam variabel uses \& activity, dan welcoming dalam variabel sociability. Atribut-atribut yang berada dalam kuadran B memiliki kinerja yang tergolong tinggi dan kepentingan yang tinggi. Atribut-atribut tersebut dapat dikatakan telah sesuai dengan harapan pengunjung Taman Siring Pierre Tendean dimana pengunjung merasa cukup puas terhadap kinerja atribut-atribut yang dianggap penting untuk ada di Taman Siring Pierre Tendean.

3. Kuadran C (Prioritas Rendah)

Atribut-atribut yang berada pada kuadran $\mathrm{C}$ pada diagram kartesius adalah history dan spirituality yang termasuk dalam variabel comfort \& image, connectedness yang termasuk dalam variabel access \& linkage, affordability, fun, usefullness, dan vitality yang termasuk dalam variabel uses \& activity, stewardship, neighbourness, dan interactivity yang termasuk dalam variabel sociability. Atribut-atribut yang berada pada kuadran $\mathrm{C}$ memiliki kinerja yang rendah dan kepentingan yang dianggap rendah oleh pengunjung Taman Siring Pierre Tendean.

4. Kuadran D (Berlebihan) 
Atribut-atribut yang berada di kuadran D pada diagram kartesius adalah readibility, realibility, dan proximity) yang termasuk dalam variabel access \& linkage, sustainability dan celebration yang termasuk dalam variabel uses \& activity, pride dan diversity yang termasuk dalam variabel sociability. Atribut-atribut yang berada di kuadran D memiliki kinerja yang tinggi dan kepentingan yang rendah. Atribut-atribut pada kuadran D memiliki tingkat kinerja yang tinggi dan tingkat kepentingan yang rendah dimana masyarakat menilai bahwa keempat atribut tersebut telah memuaskan pengunjung lebih dari yang diharapkan.

\section{Keterikatan Masyarakat Pada Taman Siring Pierre Tendean (Place Attachment)}

Place attachment berkaitan sangat kuat dengan bagaimana keakraban dan intensitas seseorang mengunjungi suatu tempat (William, et al, 1992). Semakin sering seseorang mengunjungi suatu tempat maka akan menimbulkan suatu hubungan yang positif antara orang dan tempat tersebut. Adanya kepuasan masyarakat terhadap tempat tertentu akan menimbulkan keterikatan masyarakat terhadap suatu tempat. Place attachment menggambarkan bagaimana masyarakat terikat dengan suatu tempat. Terdapat 2 (dua) komponen dalam penilaian place attachment, yaitu place identity dan place dependance. Place identity menggambarkan bagaimana suatu tempat dapat mendefinisikan seseorang, sedangkan place dependance menggambarkan bagaimana tempat dapat menyediakan fasilitas bagi aktivitas yang dilakukan seseorang.

Tabel 6. Penilaian atribut place attachment

\begin{tabular}{|c|c|c|c|c|c|c|c|c|c|c|}
\hline \multirow{2}{*}{ No } & \multirow{2}{*}{ Kode } & \multirow{2}{*}{ Atribut } & \multicolumn{5}{|c|}{ Jumlah Jawaban (orang) } & \multirow{2}{*}{$\begin{array}{l}\text { Total } \\
\text { Nilai }\end{array}$} & \multirow{2}{*}{$\begin{array}{l}\text { Rata- } \\
\text { Rata }\end{array}$} & \multirow{2}{*}{ Klasifikasi } \\
\hline & & & 1 & 2 & 3 & 4 & 5 & & & \\
\hline \multicolumn{11}{|c|}{ Place Identity (Y1) } \\
\hline 1 & Y1.1 & Ruang bagian dari diri & 5 & 21 & 47 & 31 & 16 & 392 & 3,27 & Tinggi \\
\hline 2 & Y1.2 & Ruang spesial bagi seseorang & 4 & 19 & 51 & 27 & 19 & 398 & 3,32 & Tinggi \\
\hline 3 & Y1.3 & Identifikasi diri dengan ruang & 1 & 22 & 52 & 41 & 4 & 385 & 3,21 & Tinggi \\
\hline 4 & Y1.4 & Terikat dengan ruang & 5 & 19 & 53 & 42 & 1 & 375 & 3,13 & Tinggi \\
\hline 5 & Y1.5 & Ruang menggambarkan diri seseorang & 2 & 22 & 53 & 30 & 13 & 390 & 3,25 & Tinggi \\
\hline 6 & Y1.6 & Ruang memiliki arti bagi seseorang & 3 & 21 & 61 & 32 & 3 & 371 & 3,09 & Tinggi \\
\hline \multicolumn{8}{|c|}{ Rata-Rata Place Identity } & 385,17 & 3,21 & Tinggi \\
\hline \multicolumn{11}{|c|}{ Place Dependance (Y2) } \\
\hline 1 & Y2.1 & $\begin{array}{l}\text { Ruang melakukan aktivitas yang } \\
\text { disukai }\end{array}$ & 2 & 10 & 57 & 45 & 6 & 403 & 3,36 & Tinggi \\
\hline 2 & Y2.2 & Ruang tidak dapat dibandingkan & 4 & 40 & 40 & 30 & 6 & 354 & 2,95 & Rendah \\
\hline 3 & Y2.3 & Ruang memberikan rasa lebih puas & 2 & 26 & 21 & 49 & 22 & 423 & 3,53 & Tinggi \\
\hline 4 & Y2.4 & $\begin{array}{l}\text { Penting untuk melakukan aktivitas } \\
\text { yang disukai pada suatu ruang }\end{array}$ & 1 & 38 & 28 & 30 & 23 & 396 & 3,30 & Tinggi \\
\hline 5 & $\mathrm{Y} 2.5$ & Ruang tidak dapat tergantikan & 5 & 40 & 28 & 47 & 0 & 357 & 2,98 & Rendah \\
\hline 6 & Y2.6 & $\begin{array}{l}\text { Menikmati melakukan aktivitas pada } \\
\text { suatu ruang yang mirip }\end{array}$ & 0 & 22 & 28 & 46 & 24 & 432 & 3,60 & Tinggi \\
\hline \multicolumn{8}{|c|}{ Rata-Rata Place Dependance } & 394,17 & 3,28 & Tinggi \\
\hline \multicolumn{8}{|c|}{ Rata-Rata Place Attachment } & 389,67 & 3,25 & Tinggi \\
\hline
\end{tabular}

Berdasarkan Tabel 5 dapat diketahui bahwa semua atribut variabel place identity termasuk dalam klasifikasi tinggi. Setiap atribut berada dalam rentang nilai rata-rata 3,01-4,00, sehingga termasuk dalam kategori tinggi. Hal tersebut menunjukkan bahwa Taman Siring Pierre Tendean cukup dapat menggambarkan diri masyarakat, memberikan perasaan spesial, merupakan identitas masyarakat, berarti bagi masyarakat, bagian dari diri masyarakat, dan masyarakat cukup terikat dengan Siring Jalan Pierre Tendean. Selain itu, selanjutnya dilakukan perhitungan untuk mengetahui klasifikasi variabel place identity berdasarkan rata-rata dari total ratarata semua atribut place identity. Hasil menunjukkan bahwa rata-rata untuk variabel place identity, yaitu 3,21 yang termasuk dalam rentang klasifikasi tinggi. Hal tersebut menunjukkan bahwa masyarakat merasa Taman Siring Pierre Tendean cukup dapat memberikan ikatan yang emosional dan memberikan makna terhadap hidup. Siring Jalan Pierre Tendean memberikan arti pada masyarakat. Arti Taman Siring Pierre Tendean bagi masyarakat yaitu siring 
dapat menggambarkan kebudayaan masyarakat Kota Banjarmasin dan kehidupan sehari-hari masyarakat.

Berdasarkan Tabel 5 dapat diketahui juga bahwa terdapat 2 (dua) atribut place dependance yang termasuk dalam klasifikasi rendah (rentang nilai rata-rata 2,01-3,00), yaitu atribut ruang tidak dapat dibandingkan (Y2.2) dan ruang tidak dapat tergantikan (Y2.5). Hal tersebut dikarenakan cukup banyak pengunjung yang menilai tidak setuju terhadap kedua atribut tersebut. Ketidaksetujuan pengunjung dikarenakan adanya tempat lain yang dapat dibandingkan dan menggantikan Taman Siring Pierre Tendean. Selain itu, keempat atribut lainnya termasuk dalam klasifikasi tinggi (rentang nilai rata-rata 3,01-4,00). Variabel place dependance secara keseluruhan juga termasuk dalam klasifikasi tinggi, dengan nilai rata-rata 3,28. Tingginya nilai rata-rata place dependace didukung dengan banyaknya fasilitas yang terdapat di Taman Siring Pierre Tendean untuk mengakomodasi aktivitas yang dilakukan masyarakat. Taman Siring Pierre Tendean telah menyediakan berbagai macam aktivitas, seperti lampu taman, tempat duduk, tempat sampah, toilet, signage, fasilitas olahraga, fasilitas bermain anak, dan lainnya yang menyebabkan nilai rata-rata place dependance tinggi. Berdasarkan rata-rata nilai variabel place identity dan place dependance, dapat diketahui rata-rata nilai untuk place attachment, yaitu 3,25. Rata-rata nilai tersebut termasuk dalam kategori tinggi, yang apabila disandingkan dengan klasisikasi oleh Rubinstein (1984), maka termasuk dalam level keterikatan "extention attachment". Hal tersebut berarti Taman Siring Pierre Tendean dapat memberikan memori yang emosional terhadap masyarakat yang melibatkan psikologis seseorang. Memori emosional dapat berupa perasaan bangga terhadap Taman Siring Pierre Tendean yang merupakan ikon dari Kota Banjarmasin dan memori lain yang beperngaruh terhadap emosional seseorang dengan Taman Siring Pierre Tendean.

Atribut dari place identity dan place dependance juga digunakan untuk melakukan penilaian terhadap keterikatan seseorang pada Taman Siring Pierre Tendean. Keterikatan seseorang pada suatu tempat akan berbeda antara satu dengan yang lainnya, karena adanya perbedaan perasaan yang dirasakan pada suatu tempat. Tingkat place attachment atau keterikatan masyarakat pada Taman Siring Pierre Tendean diklasifikasikan menjadi 4 (empat) klasifikasi berdasarkan nilai dari skala likert.

\section{Tabel 7. Klasifikasi place attachment} masyarakat

\begin{tabular}{ccccc}
\hline No & $\begin{array}{c}\text { Rentang } \\
\text { Nilai }\end{array}$ & $\begin{array}{c}\text { Jumlah } \\
\text { Respon- } \\
\text { den }\end{array}$ & $\begin{array}{c}\text { Klasifikasi } \\
\text { Keterikatan }\end{array}$ & Persentase \\
\hline 1 & $12-24$ & 2 & $\begin{array}{c}\text { Tidak terikat } \\
\text { sama sekali }\end{array}$ & $1,67 \%$ \\
\hline 2 & $25-36$ & 47 & $\begin{array}{c}\text { Cenderung } \\
\text { tidak terikat }\end{array}$ & $39,17 \%$ \\
\hline 3 & $37-48$ & 53 & $\begin{array}{c}\text { Cenderung } \\
\text { terikat }\end{array}$ & $44,17 \%$ \\
\hline 4 & $49-60$ & 18 & $\begin{array}{c}\text { Sangat } \\
\text { terikat }\end{array}$ & $15,00 \%$ \\
\hline & Total & $\mathbf{1 2 0}$ & & $\mathbf{1 0 0 \%}$ \\
\hline
\end{tabular}

Berdasarkan Tabel 6 dapat diketahui bahwa mayoritas pengunjung merasa bahwa mereka cenderung terikat dengan Taman Siring Pierre Tendean. Masyarakat cenderung terikat dengan taman berkaitan dengan kepuasan masyarakat terhadap Taman Siring Pierre Tendean. Menurut Bonnes dan Secchiaroli (1995), keterikatan seseorang pada suatu ruang akan membentuk ikatan yang positif yang disebabkan oleh adanya kepuasan terhadap ruang tersebut (dalam Najafi dan Kamal, 2012). Berdasarkan hasil IPA, dapat diketahui bahwa terdapat 17 atribut (berada pada kuadran B dan D) dari 31 atribut memiliki nilai kinerja yang dinilai telah sesuai dan melebihi kepentingannya. Hal tersebut menunjukkan bahwa masyarakat telah merasa cukup puas terhadap Taman Siring Pierre Tendean dan cenderung merasa terikat dengan taman. Taman Siring Pierre Tendean merupakan ikon dari Kota Banjarmasin dan merupakan salah satu destinasi wisata di Kota Banjarmasin yang terletak tepat di tengah Kota Banjarmasin. Pengunjung dapat melakukan berbagai macam aktivitas dari pagi hingga malam di Taman Siring Pierre Tendean. Taman Siring Pierre Tendean merupakan kebanggaan masyarakat Kota Banjarmasin karena terdapat banyak daya tarik yang menggambarkan kebudayaan khas Banjar. Daya tarik utama yang dimiliki oleh Taman Siring Jalan Pierre Tendean adalah Pasar Terapung, Menara Pandang, Patung Bekantan, Rumah Anno 1925, aktivitas kuliner khas banjar, dan wisata susur sungai.

\section{Hubungan Kualitas Taman Sebagai Ruang Publik Terhadap Keterikatan Masyarakat Pada Taman Siring Pierre Tendean}

\section{Uji normalitas}

Uji normalitas yang dilakukan dalam penelitian ini menggunakan One-Sample Kolgomorov-Smirnov. Uji normalitas One-Sample Kolgomorov-Smirnov menggunakan nilai 
unstandardized residual dari variabel $\mathrm{X}$ dan variabel Y. Penelitian ini memiliki (dua) sub variabel $\mathrm{Y}$, yaitu place identity (Y1) dan place dependance (Y2). Data yang digunakan terdistribusi normal apabila nilai signifikansi lebih besar daripada 0,05. Berdasarkan hasil uji normalitas menggunakan One Sample Kolmogorov-Smirnov dapat diketahui bahwa nilai signifikansi unstandardized residual antara variabel $\mathrm{X}$ dengan $\mathrm{Y} 1$ (place identity) dan $\mathrm{Y} 2$ (place dependance) masing-masing adalah 0,200. Berdasarkah hasil uji normalitas, dapat diketahui bahwa kedua sub variabel, place identity (Y1) dan place dependance (Y2), memiliki data yang terdistribusi secara normal.

\section{Uji linieritas}

Uji linearitas dilakukan untuk mengetahui apakah antara variabel $\mathrm{X}$ dan $\mathrm{Y}$ terdapat hubungan yang linier. Uji linearitas dilakukan dengan menggunakan Compare Mean. Variabel X dan Y dikatakan memiliki hubungan yang linier apabila memiliki nilai signifikansi dari deviation from linearity lebih besar dari 0,05 . Nilai signifikansi variabel comfort \& image (X1) dengan place identity (Y1) memiliki nilai 0,451 dan nilai signifikansi dengan place dependance (Y2) memiliki nilai 0,324 . Nilai signifikansi variabel access \& linkage (X2) dengan place identity (Y1) memilki nilai 0,332 dan dengan place dependance (Y2) memiliki nilai 0,724. Nilai signifikansi variabel uses \& activity (X3) dengan place identity (Y1) memilki nilai 0,891 dan dengan place dependance (Y2) memiliki nilai 0,660. Nilai signifikansi variabel sociability $(\mathrm{X} 4)$ dengan place identity (Y1) memilki nilai 0,632 dan dengan place dependance (Y2) memiliki nilai 0,263. Berdasarkan hasil uji linear diketahui bahwa keempat variabel kualitas taman memiliki hubungan yang linier dengan variabel place attachment.

\section{Hubungan kualitas Taman Siring Pierre Tendean dengan place attachment}

Analisis korelasi menghasilkan nilai korelasi yang menjadi dasaran dalam menentukan kuat hubungan antara variabel X dan Y. Selain itu terdapat nilai signifikansi yang menjadi dasaran dalam pengambilan keputusan dalam menentukan ada tidaknya hubungan antara variabel $\mathrm{X}$ dan variabel Y. Apabila nilai signifikansi $<0,05$, maka H0 ditolak dan H1 diterima, dan apabila nilai signifikansi >0,05 maka $\mathrm{H} 0$ diterima dan $\mathrm{H} 1$ ditolak. Hipotesis yang digunakan dalam penelitian ini adalah sebagai berikut.
H0 = Tidak ada hubungan antara kualitas Taman Siring Pierre Tendean dengan place attachment pada Taman Siring Pierre Tendean

H1 = Ada hubungan antara kualitas Taman Siring Pierre Tendean dengan place attachment pada Taman Siring Pierre Tendean

Tabel 8. Hasil korelasi sub variabel kualitas taman dengan place identity

\begin{tabular}{|c|c|c|c|c|c|}
\hline \multirow[b]{2}{*}{$\begin{array}{l}\text { Ko } \\
\text {-de }\end{array}$} & \multirow{2}{*}{$\begin{array}{c}\text { Sub } \\
\text { Variabel } \\
\text { Kualitas } \\
\text { Taman } \\
\end{array}$} & \multicolumn{2}{|c|}{ Signifikansi } & \multicolumn{2}{|c|}{ Korelasi } \\
\hline & & $\begin{array}{c}\text { Nil- } \\
\text { ai }\end{array}$ & $\begin{array}{c}\text { Ketera- } \\
\text { ngan }\end{array}$ & $\begin{array}{c}\text { Nil- } \\
\text { ai }\end{array}$ & $\begin{array}{c}\text { Tingkat } \\
\text { Hubun- } \\
\text { gan }\end{array}$ \\
\hline $\mathrm{X} 1$ & $\begin{array}{l}\text { Comfort } \\
\text { \& Image }\end{array}$ & $\begin{array}{c}0,01 \\
3\end{array}$ & $\begin{array}{c}\text { Ada } \\
\text { Hubung } \\
\text { an }\end{array}$ & $\begin{array}{c}, 226 \\
*\end{array}$ & Lemah \\
\hline $\mathrm{X} 2$ & $\begin{array}{l}\text { Access \& } \\
\text { Linkage }\end{array}$ & $\begin{array}{c}0,41 \\
1\end{array}$ & $\begin{array}{c}\text { Tidak } \\
\text { Ada } \\
\text { Hubung } \\
\text { an }\end{array}$ & & \\
\hline $\mathrm{X} 3$ & $\begin{array}{l}\text { Uses \& } \\
\text { Activity }\end{array}$ & $\begin{array}{c}0,00 \\
1\end{array}$ & $\begin{array}{c}\text { Ada } \\
\text { Hubung } \\
\text { an } \\
\end{array}$ & $\begin{array}{l}, 300 \\
* *\end{array}$ & Lemah \\
\hline $\mathrm{X} 4$ & Sociability & $\begin{array}{c}0,01 \\
0\end{array}$ & $\begin{array}{c}\text { Ada } \\
\text { Hubung } \\
\text { an }\end{array}$ & $\begin{array}{c}, 233 \\
*\end{array}$ & Lemah \\
\hline
\end{tabular}

Berdasarkan Tabel 7 dapat diketahui bahwa terdapat 3 (tiga) sub variabel kualitas taman yang memiliki hubungan dengan place identity, yaitu comfort \& image, uses \& activity, dan sociability. Hubungan berbanding lurus terjalin antara kualitas dengan place identity dan memiliki kuat hubungan yang lemah. Hal tersebut menunjukkan bahwa kepuasan pengunjung terhadap kualitas Taman Siring Pierre Tendean menyebabkan adanya hubungan yang kecil tapi pasti dengan place identity. Place identity masyarakat dapat meningkat apabila comfort \& image, uses \& activity, dan sociability Taman Siring Pierre Tendean mengalami peningkatan dan sebaliknya. Adanya hubungan juga menunjukkan indikasi adanya pengaruh antara kualitas dengan place identity. Sub variabel uses \& activity memiliki koefisien korelasi yang paling besar, yang mengindikasikan bahwa uses \& activity memberikan kontribusi yang lebih besar daripada variabel lainnya dalam membentuk place identity masyarakat.

Berdasarkan Tabel 8 dapat diketahui bahwa terdapat 2 (dua) sub variabel yang memiliki hubungan dengan place dependance, yaitu comfort \& image dan uses \& activity. Hubungan kedua variabel tersebut berbanding lurus dan memiliki kekuatan hubungan yang lemah. Hal tersebut menunjukkan bahwa adanya perubahan pada kedua atribut tersebut akan menyebabkan adanya perubahan yang kecil tapi pasti pada place 
dependance dan sebaliknya. Place dependance menggambarkan pentingnya suatu tempat menyediakan fasilitas bagi penggunanya untuk melakukan aktivitas tertentu.

Tabel 9. Hasil korelasi sub variabel kualitas taman dengan place dependance

\begin{tabular}{|c|c|c|c|c|c|}
\hline \multirow[b]{2}{*}{$\begin{array}{l}\text { Ko } \\
\text {-de }\end{array}$} & \multirow{2}{*}{$\begin{array}{c}\text { Sub } \\
\text { Variabel } \\
\text { Kualitas } \\
\text { Taman } \\
\end{array}$} & \multicolumn{2}{|c|}{ Signifikansi } & \multicolumn{2}{|c|}{ Korelasi } \\
\hline & & $\begin{array}{c}\text { Nil- } \\
\text { ai }\end{array}$ & $\begin{array}{c}\text { Ketera- } \\
\text { ngan }\end{array}$ & Nilai & $\begin{array}{c}\text { Tingkat } \\
\text { Hubun- } \\
\text { gan }\end{array}$ \\
\hline $\mathrm{X} 1$ & $\begin{array}{l}\text { Comfort } \\
\text { \& Image }\end{array}$ & $\begin{array}{c}0,00 \\
7\end{array}$ & $\begin{array}{c}\text { Ada } \\
\text { Hubung } \\
\text { an }\end{array}$ & ,244* & Lemah \\
\hline $\mathrm{X} 2$ & $\begin{array}{l}\text { Access \& } \\
\text { Linkage }\end{array}$ & $\begin{array}{c}0,09 \\
4\end{array}$ & $\begin{array}{c}\text { Tidak } \\
\text { Ada } \\
\text { Hubung } \\
\text { an } \\
\end{array}$ & & \\
\hline $\mathrm{X} 3$ & $\begin{array}{l}\text { Uses \& } \\
\text { Activity }\end{array}$ & $\begin{array}{c}0,00 \\
0\end{array}$ & $\begin{array}{c}\text { Ada } \\
\text { Hubung } \\
\text { an }\end{array}$ & $\begin{array}{c}387 * \\
*\end{array}$ & Lemah \\
\hline $\mathrm{X} 4$ & $\begin{array}{l}\text { Sociabili } \\
\text { ty }\end{array}$ & $\begin{array}{c}0,06 \\
8\end{array}$ & $\begin{array}{c}\text { Tidak } \\
\text { Ada } \\
\text { Hubung } \\
\text { an }\end{array}$ & & \\
\hline
\end{tabular}

Selanjutnya, sub variabel comfort \& image dan uses \& activity memiliki hubungan dengan place dependance, dimana Taman Siring Pierre Tendean merupakan salah satu kawasan wisata dan memiliki berbagai macam aktivitas didalamnya. Tersedianya berbagai fasilitas untuk mendukung aktivitas yang terdapat di Taman Siring Pierre Tendean membuat pengunjung ingin berkunjung ke siring. Sub variabel uses \& activity memiliki nilai koefisien korelasi 3,87, dimana nilai tersebut hampir mendekati 4 yang termasuk dalam kategori keterikatan cukup kuat, yang menunjukkan indikasi bahwa aktivitas memberikan pengaruh cukup besar terhadap place dependence.

Tabel 10. Hasil korelasi kualitas taman dengan place attachment

\begin{tabular}{llllll}
\hline & & \multicolumn{2}{c}{ Signifikansi } & \multicolumn{2}{c}{ Korelasi } \\
\cline { 3 - 6 } $\begin{array}{c}\text { Ko } \\
\text {-de }\end{array}$ & $\begin{array}{c}\text { Variabe } \\
\mathbf{l}\end{array}$ & Nilai & $\begin{array}{c}\text { Ketera- } \\
\text { ngan }\end{array}$ & Nilai & $\begin{array}{c}\text { Tingkat } \\
\text { Hubunga } \\
\text { n }\end{array}$ \\
\hline X & $\begin{array}{l}\text { Kualitas } \\
\text { Ruang } \\
\text { Publik }\end{array}$ & $\begin{array}{l}0,00 \\
0\end{array}$ & $\begin{array}{l}\text { Ada } \\
\text { Hubunga } \\
\text { n }\end{array}$ & $\begin{array}{l}, 357 \\
*\end{array}$ & Lemah \\
\hline
\end{tabular}

Secara keseluruhan Tabel 10 menunjukkan bahwa variabel kualitas Taman Siring Pierre Tendean memiliki hubungan yang berbanding lurus terhadap keterikatan masyarakat pada taman (place attachment) dengan kuat hubungan yang lemah. Kuat hubungan yang lemah menggambarkan bahwa adanya perubahan pada kualitas Taman Siring Pierre Tendean akan menyebabkan adanya perubahan yang kecil tapi pasti pada place attachment. Adanya hubungan antara kualitas taman dengan place attachment menggambarkan adanya indikasi bahwa kualitas memberikan pengaruh pada place attachment di Taman Siring Pierre Tendean. Adanya hubungan yang lemah antara kualitas taman dengan place attachment menggambarkan adanya indikasi faktor lain diluar penelitian yang dilakukan yang mempengaruhi kuat hubungan kualitas taman dan place attachment.

\section{KESIMPULAN}

Berdasarkan penjelasan diatas, dapat disimpulkan bahwa terdapat adanya hubungan antara kualitas taman dengan keterikatan masyarakat pada Taman Siring Pierre Tendean. Berdasarkan analisis korelasi hubungan antraa kualitas taman dengan place attachment memiliki hubungan positif yang bernilai lemah, yang menunjukkan bahwa adanya perubahan pada kualitas taman akan menyebakan adanya perubahan pada keterikatan masyarakat. Nilai hubungan yang lemah menunjukkan bahwa terdapat faktor lain diluar penelitian yang mempengaruhi kuat hubungan kualitas taman dengan place attachment. Adanya hubungan antara kualitas taman dan place attachment dapat dilihat dari kualitas taman yang cukup baik dan nilai place attachmnet yang tergolong tinggi, serta masyarakat cenderung terikat dengan Taman Siring Pierre Tendean. Place attachment bernilai tinggi dan masyarakat cenderung terikat pada Taman Siring Pierre Tendean juga dapat dilihat dari intensitas pengunjung mengunjungi taman, dimana mayoritas masyarakat mengunjungi taman 1x dalam seminggu.

Taman Siring Pierre Tendean memiliki kualitas yang cukup baik yang dapat dilihat dari 17 atribut kualitas taman berada pada kuadran B (pertahankan prestasi) dan D (berlebihan). Atribut yang berada pada kedua atribut tersebut memiliki kinerja yang telah sesuai dengan harapan pengunjung yang menunjukkan pengunjung merasa puas terhadap 17 atribut tersebut dan menimbulkan ikatan terhadap Taman Siring Pierre Tendean. Walaupun masih terdapat beberapa atribut yang perlu adanya perbaikan, terutama atribut yang berada pada kuadran A. Taman Siring Pierre Tendean memiliki kualitas yang cukup baik, sehingga membuat masyarakat sering mengunjungi taman dan menimbulkan adanya ikatan antara masyarakat dengan taman tersebut (place attachement). 


\section{DAFTAR PUSTAKA}

Carmona, Matthew et al. 2008. Public Space: The Management Dimension. New York. Routledge.

Malek, N.A., Mariapan, M., Shariff, M.K., \& Aziz, A. 2010. Assessing the quality of green open spaces: a review. Malaysia. International Islamic University Malaysia.

Najafi, Mina dan Mustafa Kamal. 2012. The Concept of Place Attachment in Environmental Psychology. Elixir Sustain Architecture. 45: 7637-7641.

Pattisinai, Amanda Ristriana. 2016. Keselamatan Berjalan Kaki Pada Bagian Crosswalk Berdasarkan Pedestrian Environment Quality Index (PEQI) Guna Mendukung Sustainable Urban Transportation. Prosiding Seminar Nasional Universitas Muhammadiyah Surakarta: 1-10.

Kementerian Pekerjaan Umum. Peraturan Menteri Pekerjaan Umum Nomor 5/PRT/M/2008.

Purnamasari, Wulan Dwi, Oktavia Indah Rudinanda, dan I Nyoman Suluh Wijaya. (2017). Tipologi dan Kualitas Penggunaan Ruang Publik Permukiman Kampung Kota Malang. Jurnal Tata Kota dan Daerah. 9 (1): 43-50.

Sasongko, W., R. P. Kurniasanti, dan J. P. Siregar. (2017). The Development Concept of Taman Aloon-Aloon Tulungagung Based on Visual Accessibility, Diversity of Activities and Perception of Users. IOP Conference Series: Earth and Environmental Science. 70:1-10.

Siregar, Syofian. 2017. Metode Penelitian Kuantitatif: Dilengkapi dengan Perbandingan Perhitungan Manual \& SPSS. Jakarta. KENCANA.

Williams, Danial R. Dan Jerry J. Vaske. 2003. The Measurement of Place Attachment: Validity and Generalizability of $A$ Psychometric Approach. Forest Science. 49(6):830-840. 
HUBUNGAN KUALITAS TAMAN TERHADAP KETERIKATAN MASYARAKAT PADA TAMAN SIRING PIERRE TENDEAN KOTA BANJARMASIN 